\title{
Notes and Announcements
}

\section{Toronto Neurology Update}

The 8th annual symposium was held at the Sutton Place Hotel, Toronto on the 29th and 30th May, 1992. There were 260 registrants. The Henry J. Barnett Lecture was given by Dr. M. Dyken on "Anti-Thrombotic Therapy in Stroke", sponsored by the Heart and Stroke Foundation of Ontario.

This symposium has proven a major event of clinical interest and in continuing medical education in neurological disorders.

\section{American Neurological Association}

The 117 th A.N.A. meeting will be held at the Royal York Hotel, Toronto, October 18-21, 1992. This is the first time the organization has met in Canada since 1973. There are four satellite symposia:

American Society for Neurological Investigation, Oct. 18

Clinical Eye Movement Society, Oct. 18

Parkinson Study group and Movement Disorder Society, Oct. 18

Society for Experimental Neuropathology, Oct. 17 and 18

\section{Continuing Accreditation in Neurology}

A presentation was made by Dr. Parboosingh (Calgary) on behalf of the Royal College of Physicians and Surgeons of Canada, at the Canadian Neurological Sciences Congress in Winnipeg, June 26, 1992. He presented preliminary plans for MOCOMP (Maintenance of Competence) pilot project.

This is an accreditation system for all disciplines, and several organizations have already expressed interest and participation.

CME will be the basis and will be expressed in three areas:

1. Self-directed, using all forms of media

2. Meetings and Symposia, e.g., hospital rounds

3. Scholarly activities

There will be a points system of credits, with an emphasis on "hands-on" update of current knowledge in the neurosciences. It is anticipated that the Canadian Neurological and Neurosurgical Societies will be closely involved in the near future.

\section{Epilepsy Canada/Parke-Davis Canada Research Fellowship}

The Epilepsy Canada/Parke-Davis Canada Research Fellowship is offered to develop expertise in clinical or basic epilepsy research and to enhance the quality of care for epilepsy patients in Canada. The award of the fellowship is $\$ 35,000$ annually. Epilepsy Canada will present the award at the annual meeting of the Canadian Congress of Neurological Sciences.

Research must be carried out at a Canadian facility, with project emphasis on the study of epilepsy itself and not on epilepsy as part of the study of another field. The Fellowship is primarily a training program and is not intended for individuals holding faculty appointments. Applicants must have an M.D. or a Ph.D. Those with an M.D. must have completed residency training.

Application forms will be available September 1, 1992. The deadline for submission is December 1, 1992. For further information, please contact Rebecca Rupp, Program Co-ordinator, Epilepsy Canada, 1470 Peel St., Suite 745, Montreal, Quebec H3A 1T1. Tel.: (514) 845-7855. Fax.: (514) 845-7866.

Bourse de Recherche Epilepsie Canada/Parke-Davis Canada

La bourse de recherche d'Epilepsie Canada/Parke-Davis Canada est offerte en vue d'encourger la recherche fondamentale ou clinique sur l'épilepsie et d'améliorer la qualité des soins aux personnes atteintes d'épilepsie au Canada. Le montant de la bourse, accordée annuellement, est de $\$ 35000$. Elle sera présentée à l'assemblée annuelle du Congrès Canadien des Sciences Neurologiques.

La recherche doit être effectuée dans une institution canadienne; le projet doit porter sur l'étude de l'épilepsie proprement dite et non sur l'épilepsie en tant que partie d'une étude sur un autre sujet. Il s'agit d'une bourse de perfectionnement et ne s'adresse pas aux chercheurs détenant déjà un poste dans une université. Les candidats doivent détenir le titre de M.D. ou de Ph.D. Ceux qui ont un M.D. doivent avoir terminé leur entraînement en spécialité.

Les formulaires de demande seront disponibles à compter du $1^{\text {er }}$ septembre 1992. Les demandes devront être soumises au plus tard le $1^{\text {er }}$ décembre 1992. Pour de plus amples renseignements, s'adressez à Rebecca Rupp, Coordonnatrice des Programmes, Epilepsie Canada, 1470 rue Peel, bureau 745, Montréal, Québec H3A 1T1. Tél.: (514) 845-7855. Fax.: (514) 845-7866. 